BIOBUSINESS BRIEFS

\title{
REGULATORY WATCH
}

\section{Structural and procedural characteristics of international regulatory authorities}

Drug reviewers in regulatory authorities (health authorities) around the world have the responsibility of evaluating safety, effectiveness and quality control data for a new drug before it is approved for marketing. The regulatory requirements, structure and processes of various regulatory authorities are different, making it challenging for pharmaceutical companies to develop drugs for simultaneous submission to all regulatory authorities. Given this variation, we comprehensively evaluated the structural and procedural characteristics of different global regulatory authorities with the aim of aiding drug development, evaluation and filing. Data were gathered from the published literature and the internet, interviews with the regulatory personnel from different regulatory authorities and a survey administered to regulatory personnel in the pharmaceutical industry. The findings are summarized in TABLE 1, and an overview of the regulatory processes for different agencies is provided in Supplementary information S1 (table).

Regulatory authorities are allocated a wide variety of budgets, the highest being the US Food and Drug Administration (FDA; US $\$ 1.23$ billion). There is also high variability in the number of technical reviewers across regulatory authorities. Of the authorities in the established major pharmaceutical markets (the United States, Europe and Japan), the FDA has the most internal reviewers $(\sim 2,000)$. The European Medicines Agency (EMA) has established a network consisting of over 4,500 experts providing scientific expertise to the agency, including those from the country-level regulatory authorities in the European Union, such as the UK's Medicines and Healthcare products Regulatory Agency (MHRA). The Japanese Pharmaceuticals and Medical Devices Agency (PMDA) has 560 reviewers. Before August 2015, the Chinese FDA had only 120 staff in its Center of Drug Evaluation to perform scientific evaluations; however, the State Council of China has since taken measures to hire and train more technical evaluators to clear the backlog of applications. By January 2017, the number of evaluators had been increased to $\sim 300$. Some authorities do not provide information on internal human resources (for example, in Russia and Brazil).

The most recent complete data on new drug application (NDA) submissions and approvals are available for 2015 and 2016. Differing definitions of NDAs or their equivalents between authorities make direct comparisons difficult (see Supplementary information S2 (box) for details), but of the

Table 1 | Budgets, product approvals, timelines and fees of various regulatory authorities for new pharmaceutical products

\begin{tabular}{|c|c|c|c|c|c|c|c|}
\hline Regulatory authority & $\begin{array}{l}\text { Budget for the } \\
\text { fiscal years } \\
2015 / 2016 \text { (in } \\
\text { US\$ millions)* }\end{array}$ & $\begin{array}{l}\text { Number of } \\
\text { technical } \\
\text { reviewers } \\
\text { in } 2016\end{array}$ & $\begin{array}{l}\text { Number of NDA } \\
\text { submissions for } \\
\text { new drugs in } \\
2015 / 2016^{\ddagger}\end{array}$ & $\begin{array}{l}\text { Number } \\
\text { of new } \\
\text { therapeutic } \\
\text { approvals in } \\
2015 / 2016^{\ddagger}\end{array}$ & $\begin{array}{l}\text { Standard } \\
\text { review } \\
\text { timelines } \\
\text { (days) }\end{array}$ & $\begin{array}{l}\text { Median time } \\
\text { for approval } \\
\text { (days) in } \\
2015\end{array}$ & $\begin{array}{l}\text { Fees per } \\
\text { NDA in } 2016 \\
\text { (in US\$ } \\
\text { thousands)* }\end{array}$ \\
\hline $\begin{array}{l}\text { European Medicines Agency } \\
\text { (EMA) }\end{array}$ & $340 / 342$ & $\sim 4,500^{\S}$ & $61 / 68$ & $39 / 27$ & 210 & $422^{\|}$ & 316 \\
\hline $\begin{array}{l}\text { US Food and Drug } \\
\text { Administration (FDA) }\end{array}$ & $1,194 / 1,230$ & $\sim 2,000$ & $35 / 41$ & $45 / 22$ & 300 & $333^{\| \prime}$ & 2,374 \\
\hline $\begin{array}{l}\text { Chinese Food and Drug } \\
\text { Administration }\end{array}$ & $199 / 250$ & $\sim 120 "$ & NA & $72 / 31^{\#}$ & 900 & 639 & 862 \\
\hline $\begin{array}{l}\text { UK Medicines and Healthcare } \\
\text { products Regulatory Agency } \\
\text { (MHRA) }\end{array}$ & $438 / 477$ & $N A^{\S}$ & NA & $146^{\star \star} / \mathrm{NA}$ & 210 & 230 & 120 \\
\hline $\begin{array}{l}\text { Central Drugs Standard } \\
\text { Control Organization (India) }\end{array}$ & 26/NA & $\sim 130$ & NA & $17 / 22$ & 270 & 523 & 1 \\
\hline Roszdravnadzor (Russia) & 55/NA & NA & NA & NA & 210 & 335 & 8 \\
\hline $\begin{array}{l}\text { Health Sciences Authority } \\
\text { (Singapore) }\end{array}$ & 146/NA & $\sim 300$ & NA & $61 / 72$ & 295 & 409 & 62 \\
\hline $\begin{array}{l}\text { Therapeutic Goods } \\
\text { Administration (Australia) }\end{array}$ & 104/NA & NA & 43 & $27 / N A$ & $255^{\neq \neq}$ & 373 & 172 \\
\hline $\begin{array}{l}\text { Brazilian Health Surveillance } \\
\text { Agency }\end{array}$ & NA/NA & NA & NA & NA & 730 & 834 & 69 \\
\hline
\end{tabular}

NA, not available; NDA, new drug application. ${ }^{\star}$ Currency conversion rates are as of 22 May $2017 .{ }^{\ddagger}$ Where possible, numbers are for NDAs for new therapeutics, such as new molecular entities approved by the US FDA's Center for Drug Evaluation and Research. Direct comparisons between regulatory authorities are not possible owing to differences in definitions; see Supplementary information S2 (box). $\$$ The EMA has a regulatory network with a pool of 4,500 scientific experts from member countries. MHRA experts are part of the EMA network. "Data from 2016. "Data from August 2015; by January 2017, this number had increased to 300. "Excludes traditional Chinese medicines. **Data includes all decentralised (concerned member state and reference member state) product licenses. ${ }^{\ddagger \neq}$ Working days. 
authorities in the established major markets, the US FDA approved the most NDAs for new drugs (45) in 2015, whereas the PMDA approved the most NDAs (48) in 2016. It is important to note that for the MHRA, the number of product approvals in TABLE 1 includes all decentralised applications (both with the UK as the reference member state and approvals from concerned member states, making 146 approvals in total), and so the actual number of unique NDAs approved may be comparable to that of the EMA.

The current standard timelines for review by different authorities vary considerably. The shortest time was 210 calendar days for the EMA, and the longest time was 900 calendar days for the Chinese FDA. However, as noted earlier, the Chinese FDA is introducing measures to accelerate the drug review and approval process, including a major expansion in the number of evaluators in its technical review team. Several of the authorities also have programmes to enable accelerated review of products that are considered to be addressing particularly important medical needs, such as the FDA's priority review designation, which is associated with a review timeline of 180 days (6 months), compared with the standard review timeline of 300 days (10 months).

Finally, the regulatory authorities' NDA review fees differ widely. India had the lowest fees (50,000 Indian rupees; $\$ 1,000$ ), whereas the FDA had the highest ( $\$ 2.3$ million).

Overall, the regulatory authorities in developed countries such as the United States, European Union, UK, Canada and Japan are more evolved in terms of regulatory systems and resources, such as technical reviewers, but have higher NDA fees. Regulatory environments are rapidly changing across the world, and it is important to understand the similarities and differences between regulatory requirements to accelerate the marketing of new medicines.

Anand B. Jain is at Novo Nordisk Healthcare AG Thurgauerstrasse 36, CH-8050 Zurich, Switzerland.

Annette Mollet and Thomas D. Szucs are at the European Center of Pharmaceutical Medicine/Institute of Pharmaceutical Medicine, University of Basel, Klingelbergstrasse 61, CH-4056 Basel, Switzerland.

Correspondence to T.D.S. thomas.szucs@unibas.ch doi:10.1038/nrd.2017.135 Published online 11 Aug 2017

Competing interests statement

The authors declare no competing interests.

SUPPLEMENTARY INFORMATION

See online article: $\underline{\mathrm{S} 1}$ (table) $\mid \underline{\mathrm{S}}$ (box)

ALL LINKS ARE ACTIVE IN THE ONLINE PDF 